\title{
The Comparative Typology of French and Georgian Journalistic Discourses
}

\author{
Mariam Pareshishvili \\ University of Patriarchate of Georgia, Georgia
}

\begin{abstract}
Some major changes that occurred in the 20th century were the result of growth of the role and influence of media. Today, print media, TV and the Internet represent integral parts of the modern world and have a significant impact on people's lives. Consequently, studying the peculiarities of informative newspaper texts, due to their topicality and importance, is one of the difficult but interesting aspects. The purpose of this article is to identify the similarities and differences that characterize French and Georgian journalistic discourses. We will also try to show stylistic-grammatical and pragmatic features of Georgian and French political articles.
\end{abstract}

Index Terms - media, journalistic discourse, standardization, speech cliches, political realia

\section{INTRODUCTION}

According to K. Djachy, linguistic diversity is the reality faced by mankind since its formation. According to the author, translation plays the most important role in bringing together civilizations (Djachy 2012, p. 1).

In the modern world, information links represent the main sources of the social-cultural progress, where newspaper is one of the best ways to inform and persuade the reader. According to D. Izachenko ${ }^{1}$, print media is an inexhaustible source of not only information, but also of linguistic material. It is impossible to deny that mass media and in particular print media strongly influence languages and causes much interest of linguists and traductologists. Print media is a separate genre, the main feature of which is an instant description of reality.

Journalistic discourse, which is a specific type of communication, has always played a great role in the formation of public opinion. Its influence is demonstrated by the fact that it is often called the fourth branch of government (or "fourth estate").

Newspaper represents one of the powerful means of providing information and raising awareness of the reader, which is intended to be both wide and heterogeneous.

Journalistic articles are characterized by diversity. News articles and messages are especially concise, businesslike and dry. In translation of this kind of texts, accuracy is achieved through syntactic and structural transformations of the sentences of the source text and through using lexical and contextual equivalents, because these changes are due to the necessity of maintaining the norms of the source language and the standards of the newspaper style.

Despite the fact that the number of newspaper texts is increased, thematic structure of the texts is not diverse and the form of newspaper reports has not changed, in fact. News reports, adverticements and journalistic texts are characterized by particular stylistic features. Exactly these types of texts form the corpus of modern mass media texts. News reports, in particular political articles, represent the foundation of mass media.

\section{METHODOLOGY}

The research methodologies used in this study cover the metods of philological research and comparative research. Using this methodology we try to show similarities and differences in French and Georgian journalistic discourses as well as the stylistic-semantic characteristics of French and Georgian journalistic discourses.

\section{RESULTS AND ANALYSIS}

Beyond the features characteristic of each genre, which, for example, distinguish analytical articles from political commentaries or from sports news we can identify some features that are generally characteristic of mass media.

One of the features of the newspaper style is the existence of standards and linguistic characteristics. It should be noted that articles are produced in a very short period of time and often there is no opportunity to get a linguistically complete article; besides, materials for a newspaper article are prepared by different journalists, who often work on their material independent of each other. Mass character of communication has a great influence on the newspaper style. Newspaper is a typical example of mass media and propaganda, as the addressees, as well as the authors, are of mass character.

\footnotetext{
${ }^{1}$ http://dea.isachenko.free.fr/
} 
The characteristics that distinguish the language of the mass media from other functional styles, as A. Mikoyan ${ }^{2}$ notes, can be grouped into following style: 1. high standards and quality of the means used; 2 . frequent use of indirect speech; 3. frequent use of narrative infinitives; 4. speech cliches, patterns and evaluative epithets; 5. political and cultural realia; 6 . stylistic techniques.

1. High standards and quality of the means used: frequent use of set expressions and cliches, different jurnalistic patterns, standard terms and nominations (characteristic of news reports and expressing the desire of their authors to create the impression of objectivity and impartiality). For example: une tension nucléaire - ठoñozrmo

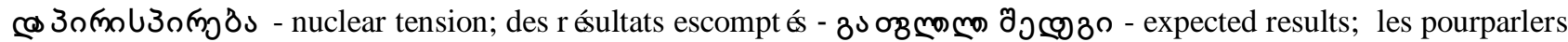
sont en cours - పo

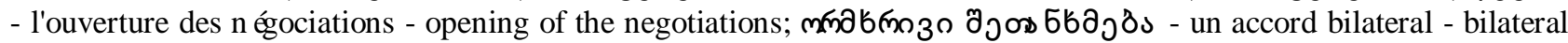

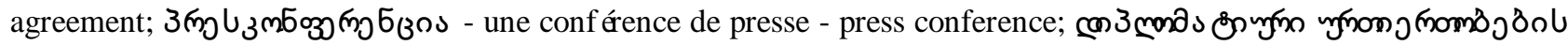

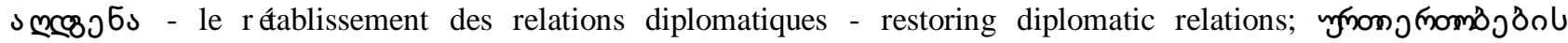

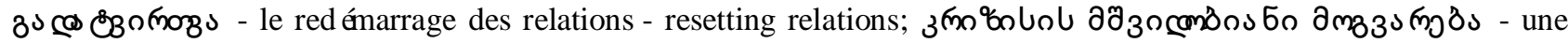

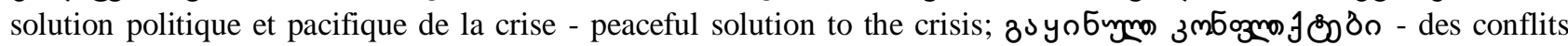

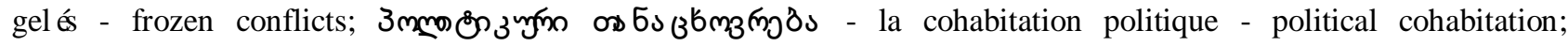

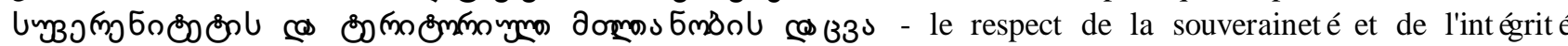
territoriale - respect for the sovereignty and territorial integrity; etc.

2. Frequent use of indirect speech is one of the stylistic characteristics of French print media which is worth noting. Journalists frequently refer to quotations from different publications. Quotations are used in parentheses or are enclosed into the discourse context with minor changes. Quotations are introduced with the help of the following declarative verbs ${ }^{3}$ : affirmer -to claim; ajouter - to add; conclure - to conclude; commenter - to comment on; constater to notice; décrire - to describe; dévoiler - to disclose; demander - to ask; déplorer - to regret; écrire - to write; évoquer to mention; estimer - to reckon; faire remarquer - to draw attention to; s'exclamer - to exclaim againt; expliquer - to explain; exposer - to show; s'interroger - to question; ironiser - to be ironic; noter - to note; poursuivre - to continue; préciser - to clarify; raconter - to tell; rappeler - to remind; remarquer - to point out; répondre - to respond; renchérir - to add; souffler - to prompt; souligner - to underline; titrer - to highlight; etc. While quoting, authors use a parenthetic clause with the help of which a referrence is made to the source.

- "Quinze mois plus tard", commente Ouest-France, "le maire de la capitale et l'ex-candidate sont en compétition

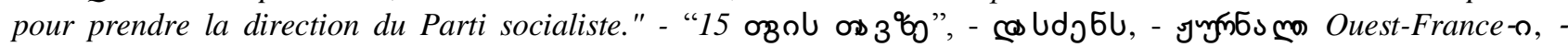

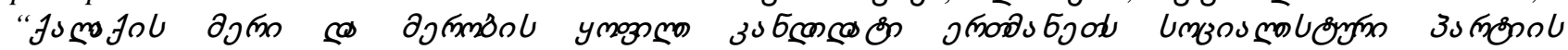

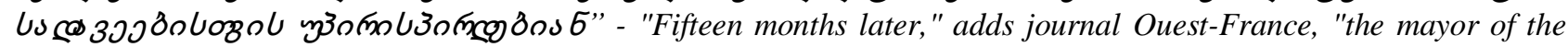
city and the former candidate compete to take the leadership of the Socialist Party

3. Frequent use of narrative infinitives is characteristic to French print media (ET+sujet+verbe déclaratif à l'infinitif). Such citations are typically used as conclusions of paragraphs and add compactness and dynamism to the article.

- Et le président candidat d'ajouter sans ciller : cela "témoigne d'une reprise économique sensible" - "oU

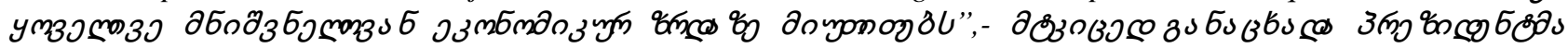

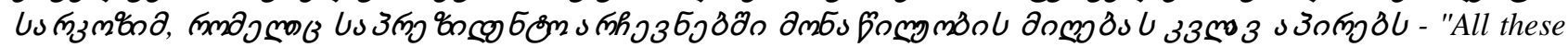
point to economic growth" - President Sarkozy, who is still going to take part in presidential elections, said firmly

4. Speech cliches, patterns and evaluative epithets belong to the category of expressions which are noteworthy among the stylistic characteristics of French print media and which have specific connotations :

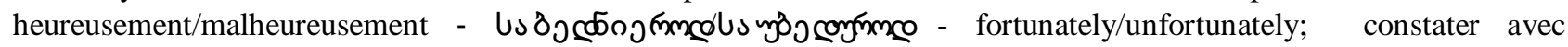
amertume - Un 5 s бymoos g $50 \beth_{3} 5 s$ - note with regret; d'une excellente qualité - s ms h

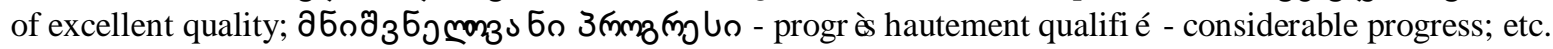

5. Multitude of various realia taken from the social, political and cultural life of a society: Le palais de l'Élysée -

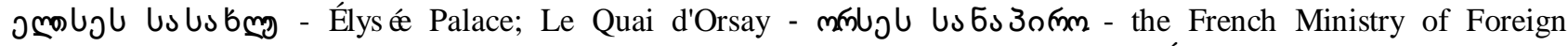
Affairs located on the Quai d'Orsay; La Guerre froide - з๐ ๐ man - cold war; Les Événements de Mai-68 - 1968

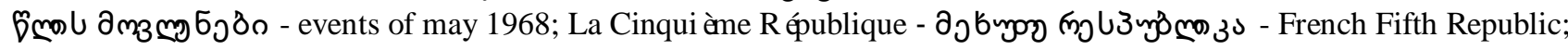

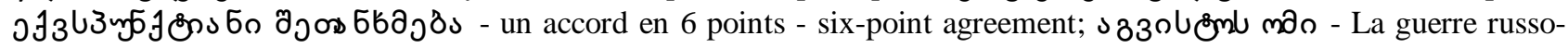
géorgienne d'août 2008 - The August war of 2008; etc.

Realia are frequently used in the products of the mass media. The main features of realia are its national and historical overtones. In our era of globalization, sometimes realia of one nation are easily transferred in another nation, for example, a lot of political realities were nonexistent in our country, such as Prime Minister, the Ombudsman, the House of Justice, NGOs, etc. that, nowadays, have found a firm ground in Georgian reality and are well-established in our country (Djachy, Pareshishvili 2014, 12).

\footnotetext{
${ }^{2}$ http://evartist.narod.ru/text12/12.htm

${ }^{3}$ http://www.rfi.fr/lffr/articles/102/article_2427.asp
} 


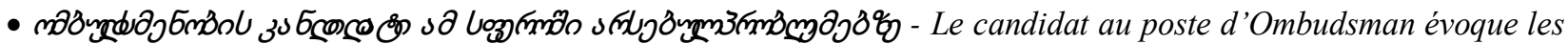
difficultés récurrentes dans ce domaine - The candidate for the post of Ombudsman talks about of the recurring difficulties in this domain

6. Print media, the function of which is to cover the facts, often uses metaphors, hyperboles, litotes, comparisons and antithesis. Stylistic techniques do not represent purely litrary phenomenon; they are widely used in print media. As a rule, the main purpose of this stylistic technique is to emphasize information. J. Gautier noted that political discourse is characterized by an abundance of metaphorical expressions (Gautier 1994, p. 140).

It should be noted that metaphor is the most common stylistic means used in print media. Metaphors are more frequently used in newspaper headlines and the titles of newspaper articles than in articles themselves. Metaphors used in the headlines and titles of newspaper articles are most original and effective among all the journalistic metaphors. It is believed that metaphors are most effective when they are persuasive in cognitive terms and, at the same time, cause emotional response. Metaphor has persuasive power, as it combines pragmatic, cognitive and linguistic knowledge, reflecting culture, ideology and history (Charteris-Black 2004).

The following are most frequently used metaphors in the French journalistic discourse: La scène politique

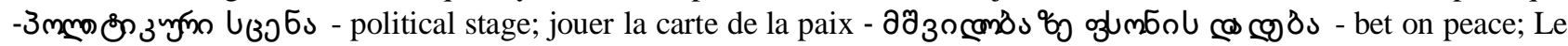

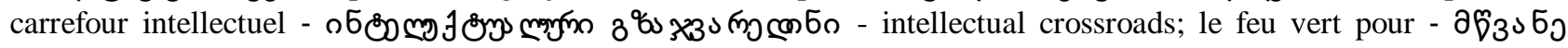

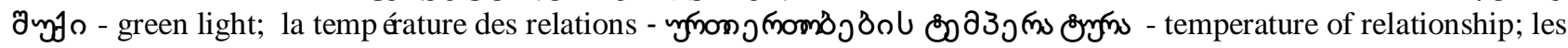

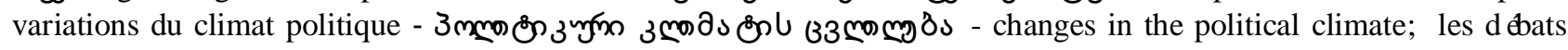
orageux - $\left.\beta^{b}\right\lrcorner$ m versa to downplay the significance of a given event. Typically, in doing so, they try to attract the reader's attention. The reader, in turn, has to carefully study the information in order to realistically assess the events and situations.

We should note that Georgian journalists are especially fond of dramatizing any situation. Consequently, stylistic techniques such as a metaphor and metonymy are quite often used in Georgian print media. However, use of literary means is typical of Georgian as well as of French print media. This way, journalists try to influence and attract the attention of the reader.

In Georgian as well as French journalistic discourse we quite often come across the metaphors, such as $\partial \partial\lrcorner$ nomo mo

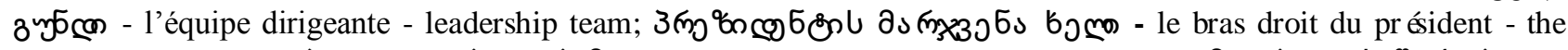

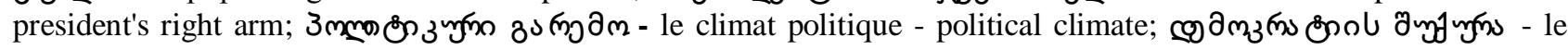

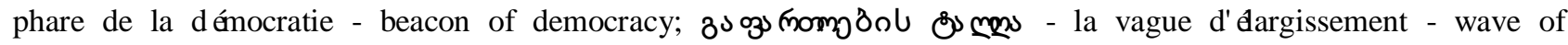

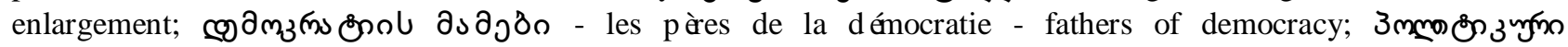

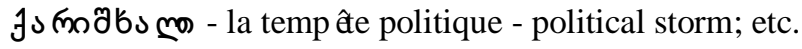

Print media often uses military metaphors. Military metaphors are quite common stylistic means used in headlines and titles of newspaper article, and the purpose of their use is to impress the readers. Military metaphors are frequently used in Georgian print media: "Озмбмдозу

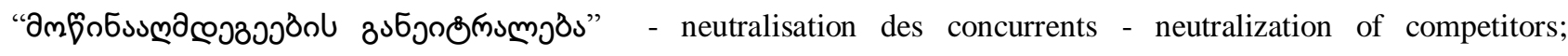

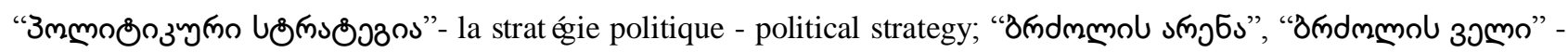

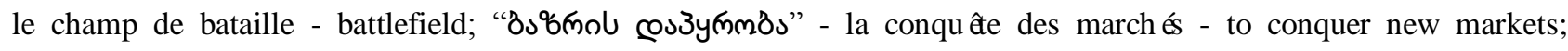

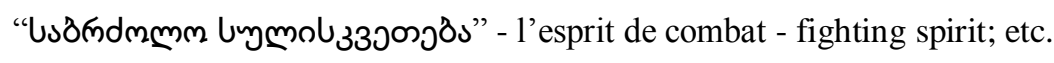

Metonymy is widely used in French journalistic discourse, one of the notable examples of which is the use of nominations of places and toponyms that stand for government institutions (Lecolle 2001, p. 163). For example:

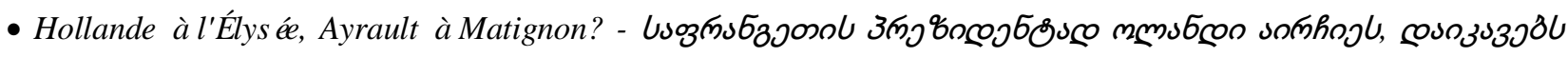

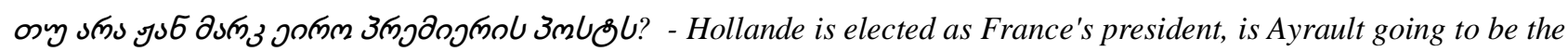
Prime Minister

Metonymy is a stylistic technique, which is also often used in the Georgian media. For example:

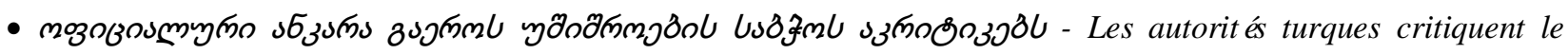
Conseil de sécurité de l'ONU - Official Ankara criticizes UN Security Council

The analysis showed that print media widely uses phraseological units, such as: l'épée de Damoclès - sword of

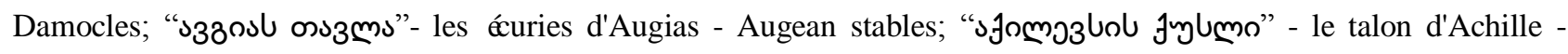

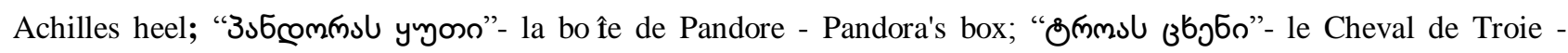

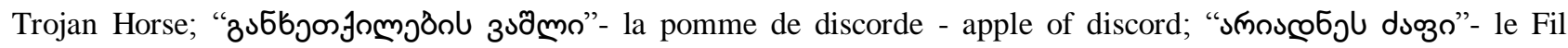

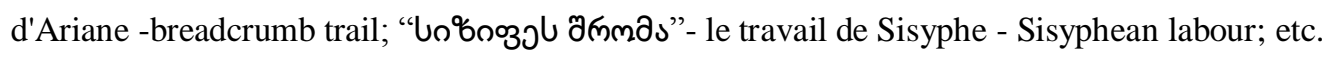




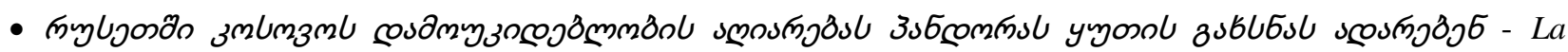
reconnaissance de l'indépendance du Kosovo est comparée en Russie à l'ouverture d'une boîte de Pandore Recognition of Kosovo's independence, in Russia, is compared to the opening of Pandora's Box

Grammatical ellipses are often used in headlines and the titles of newspaper articles. Omittion of the verb "Être"ymoz6s -"to be" is common in French headlines:

- Élections en Ukraine: la corruption en toile de fond - Elections in Ukraine: corruption in the background

Elliptical forms are used in Georgian headlines as well, though we believe that this is the result of the influence of English print media and is not acceptable for the norms of Georgian language. For example:

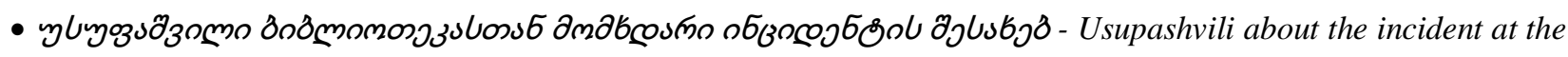
library

Frequent use of clichés is characteristic to French as well as to Georgian media. Use of newspaper clichés is one of the important components of media texts. Clichés are not only used regularly in print media, but, as T. Dobrosklonskaia notes, often repeated in the form of finished information product (Dobrosklonskaia 1986, p. 106).

\section{DisCUSSIONS AND CONCLUSIONS}

Based on the analysis of political articles the following can be concluded:

1. French as well as Georgian journalistic discourse mainly use the present tense, which is the result of the principle of economy, as well as the main function of newspaper headlines, which lies in the "actualization" of information.

- Cameron et Merkel imposent l'austérité à Hollande - Cameron and Merkel insist on austerity measures

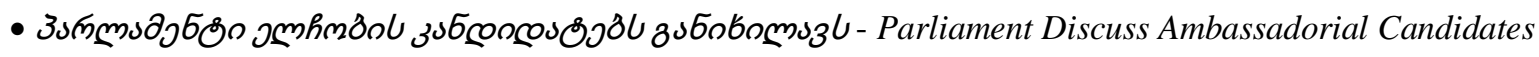

2. Grammatical ellipses are often used in journalistic discourse. Omittion of the verb "Être"-ymoz $6 \mathrm{~s} / \mathrm{to}$ be/ is common in French headlines.

3. The abbreviations that stand for international organizations are widely used in French and Georgian print media:

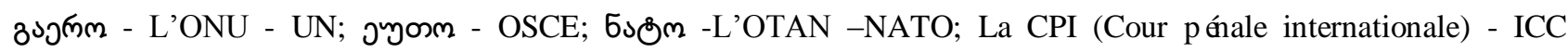
(the International Criminal Court), Le FMI (Fonds monétaire international) - IMF (International Monetary Fund); BIRD (Banque internationale pour la reconstruction et le développement) - IBRD (the International Bank for Reconstruction and Development).

4. A headline or a title of newspaper articles can be presented in the form of a simple or complex sentence.

- Paris hausse le ton contre le Hezbollah - Paris raises the voice against Hezbollah

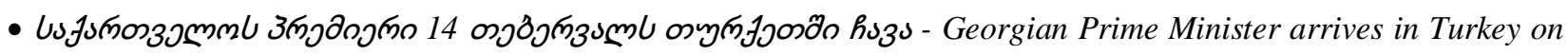
February 14

However, some of the Georgian newspapers prefer long titles and difficult structural. For example:

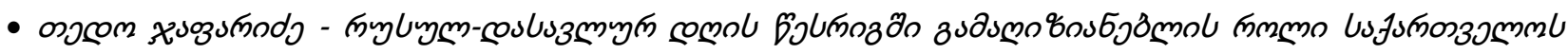

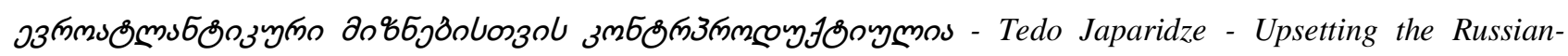
Western agenda is counterproductive for Georgia in its strive to meet Euro-Atlantic goals

5. Indirect speech is used in both French and Georgian journalistic discourses.

- Le président français Hollande déclare qu'il ne vient en Algérie pas pour "faire repence ou excuse" - French President Hollande says the purpose of his visit to Algeria is not to "repent or apologize"

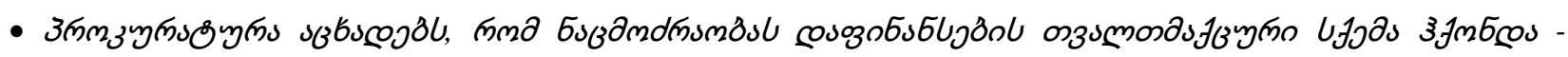
Prosecutor's office declares that the National Movement had a hypocritical funding scheme

6. Passive voice is widly used in French as well as Georgian journalistic discourses.

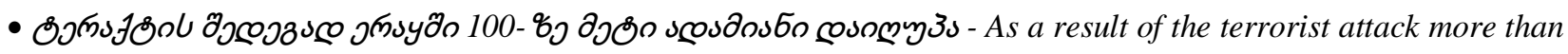
100 people were killed in Iraq

- Une enquête est lancée, Juncker parlera jeudi - The investigation is launched, Juncker announced on Thursday

7. Frequent ise of clichés is characteristic to French as well as Georgian print media. Use of newspaper clichés is one of the important components of media texts. Newspaper style is distinguished by a high degree of standardization and stylistic peculiarities.

Besides the similarities, which is generally characteristic to print media, there are some differences in French and Georgian newspaper discourses, such as:

1. Use of the titles consisting of two phrases is common in French print media, whereas such titles are used less in Georgian journalistic tradition. For example:

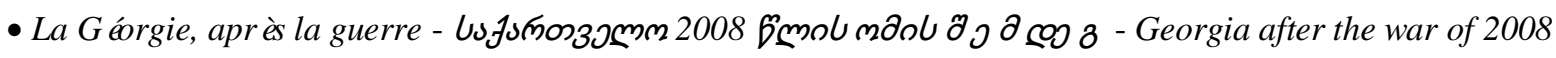


2. Use of initials of the names of famous people is frequent in French print media, unlike Georgian print media. For example: MAM - Michèle Alliot-Marie, DSK - Dominique Strauss-Kahn etc. For example:

- DSK déclare qu'il n'est plus "dans l'action" mais "la réflexion" - DSK says he is no longer "in action" but "in reflection"

3. Anglicisms are frequently used in French headlines and the titles of newspaper articles. Anglicisms are also used in Georgian print media; however, they are more often used in newspaper articles than in headlines and the titles of newspaper articles. For example:

- Notre-Dame: le happening des Femen fortement critiqué - Notre Dame: Femen demonstration strongly criticized

- Opération anti hold-up dans la ville - Anti-crime operation in the city

4. French print media is characterized by the use of the prepositional infinitives.

- Biden: les Etats-Unis prêts à engager un dialogue direct avec l'Iran - Biden: U.S. ready to engage in a direct dialogue with Iran

5. Omittion of article is characteristic to French print media, which is done for the purpose of conciseness. For example:

- Affaire Sonatrach, Chakib Khelil ciblé par la justice - Scandal involving Sonatrach, arrest warrant against Chakib Khelil

6. Use of quotations is frequent in French print media. Full name of the author of the words enclosed in parentheses typically comes before a quotation and is followed by a colon.

Joly: "Hollande veut combattre la finance avec un sabre de bois" - Joly: "Holland wants to fight crisis with a wooden sword"

7. In headlines or titles of French newspaper articles the names of officials come first and their positions next, whereas in Georgian headlines and titles of newspaper articles, the positions of officials come first and their full names are written next. For example:

- France: Jean-Marc Ayrault, un Premier ministre à la fibre africaine

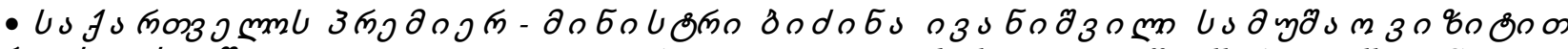

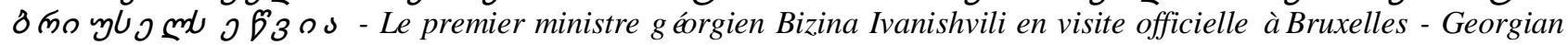
Prime Minister Bidzina Ivanishvili pays a working visit to Brussels

Understanding and translating newspaper headlines and the titles of newspaper articles is a serious challenge and requires a range of skills from a translator. From Deontological viewpoint, the role of the translator is crucial. The translator should be aware of what he/she is translating. (Djachy 2012, p. 5).

Print media depicts current developments in real time. Naturally, sharp decline in speech culture is reflected by media as well. In order to timely inform readers about ongoing developments, reporters have to prapare articles in the shortest period of time, therefore, they do not have the time to pay attention to the language they use in the articles, which clearly manifests itself in the daily newspapers, mainly in the news media. Print media is experiencing constant change and is quite diverse in terms of style. Therefore, the newspaper language has always been an object of criticism.

While translating newspaper headlines and the titles of newspaper articles special attention should be paid to the stylistic, semantic and pragmatic peculiarities of the discourse of this type. It should be noted that the quality of the translation depends on the experience accumulated in a particular field (Djachy 2011, p. 192). Majority of newspaper articles are of informational naature. Successful translation of this type of texts requires good knowledge of the characteristics and peculiarities of the newspaper style from the translator. According to K. Djachy, the main purpose of translation is to ensure communication between people speaking different languages. The greater the cultural differences, the more difficult are the problems translators face, since translation, which serves as a mediator between languages and cultures, requires from the translator not only an in-depth knowledge of the two languages but also of the implicit cultures (Djachy 2012, p. 391).

\section{REFERENCES}

[1] Charteris-Black, J. (2004). Corpus Approaches to Critical Metaphor Analysis. New York: Palgrave MacMillan http://sitestest.uclouvain.be/rec/index.php/rec/article/viewFile/341/321 (accessed 20/01/2014).

[2] Djachy, K. \& Pareshishvili, M. (2014). Realia as carriers of national and historical overtones. Theory and Practice in Language Studies Vol. 4, 1, 8-14.

[3] Djachy, K. (2011). La terminologie économique en français et les problèmes de sa traduction en géorgien. Scolia, revue de linguistique de l'Université de Strasbourg 25, 187-198.

[4] Djachy, K. (2012). Les difficultés de la traduction du texte juridique et l'interculturel. Lexiques, Identités, Cultures (Perluigi Ligas, Paolo Frassi, ed), Qui Edit, Verona 389-402.

[5] Djachy, $\mathrm{K}$. www.observatoireplurilinguisme.eu/images/Evenements/3e_Assises/Programme_et_contributions/culture/article_djachy.doc (accessed 25/01/2014).

[6] Dobrosklonskaya, T. G. (1986). Voprosi izucheniya mediatekstov.Opyt issledovaniya sovremennoy angliyskoy mediarechi. Moskva: Editorial.

[7] Gauthier, G. (1994). La métaphore guerrière dans la communication politique. Recherches en communication $\mathrm{n}^{\circ} 1$ http://nzaher710.free.fr/pdf/321.pdf (accessed 20/01/2014). 
[8] Lecolle, M. (2001). Métonymie dans la presse écrite: entre discours et langue. TRANEL 34-35, 153-170. https://doc.rero.ch/record/19624/files/13_Lecolle.pdf (accessed 5/01/2014).

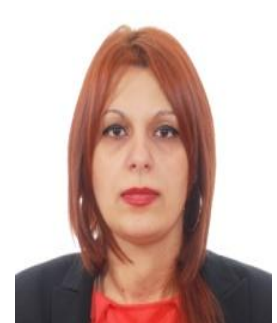

organizations.

Mariam Pareshishvili was born on November 9, 1978 in Tbilisi, Georgia. In 1996 she finished school N 167. In 2001 she completed a full academic course of the Tbilisi Ilia Chavchavadze State University of Language and culture (translator-Interpreter). In 2001 she was enrolled in the Department of Simultaneous Interpretation and was granded the qualification of simultaneous Interpreter. In 2013 she defended the doctoral dissertation in translations studies (the degree of doctor of philosophy in philology) in Ilia State University in Georgia. In 2011 she has the probation in ESIT, Graduate School of Translation and Interpreting (Université de la Sorbonne Nouvelle).

From 2008 she is french teacher in Georgian University of Patriarchate. Since 2003 she was teacher of translation at the Department of Simultaneous Interpretation. Since 2003 she is simultaneous interpreter (French-Georgian-French) and has participated in Conferences, organized by International

Dr.Pareshishvili is member of International Centre for French Studies. Since 2010 she is member of Association of Translator and Interpreters. She had participated in International and local Conferences. Author of 11 scientific publications.

1. K. Djachy, M. Pareshishvili, The terms of translation of political newspaper articles headlines from French to Georgian, (in English) in USA \& Sino-US English Teaching, EBSCO, Ulrich; 2012, volume 10, serial number 2, February, pp. 966-973;

2. La traduction des métaphors dans les titres de presse Le Linguiste revue international en sciences du language Numero 3/automne 2012 ISSN 2251-970X

3. K. Djachy, M. Pareshishvili (2014) Realia as Carriers of National and Historical Overtones (in English) Theory and Practice in Language Studies, Vol. 4, No. 1, pp. 8-14, January 2014 ACADEMY PUBLISHER 